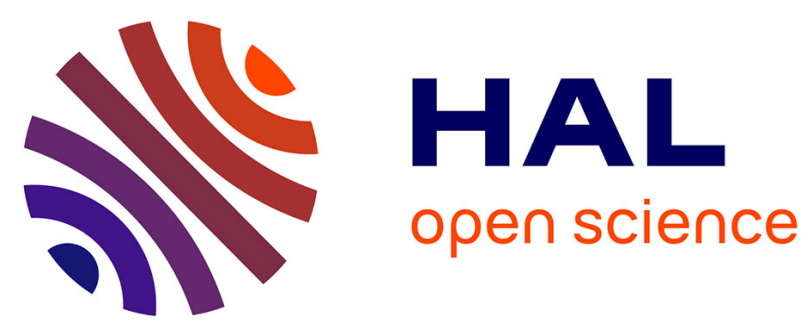

\title{
Acute and chronic stress differently affect visceral sensitivity to rectal distension in female rats
}

S. Bradesi, Hélène Eutamène, Rafael Garcia Villar, Jean Fioramonti, Lionel Bueno

\section{- To cite this version:}

S. Bradesi, Hélène Eutamène, Rafael Garcia Villar, Jean Fioramonti, Lionel Bueno. Acute and chronic stress differently affect visceral sensitivity to rectal distension in female rats. Journal of Neurogastroenterology and Motility, 2002, 14, pp.75-82. hal-02679717

\section{HAL Id: hal-02679717 https: / hal.inrae.fr/hal-02679717}

Submitted on 31 May 2020

HAL is a multi-disciplinary open access archive for the deposit and dissemination of scientific research documents, whether they are published or not. The documents may come from teaching and research institutions in France or abroad, or from public or private research centers.
L'archive ouverte pluridisciplinaire HAL, est destinée au dépôt et à la diffusion de documents scientifiques de niveau recherche, publiés ou non, émanant des établissements d'enseignement et de recherche français ou étrangers, des laboratoires publics ou privés.

\section{()(1)(2)}

Distributed under a Creative Commons Attribution - ShareAlikel 4.0 International 


\title{
Acute and chronic stress differently affect visceral sensitivity to rectal distension in female rats
}

\author{
S. BRADESI, ${ }^{\star}$ H. EUTAMENE, $\dagger$ R. GARCIA-VILlAR, ${ }^{\star}$ J. FIORAMONTI, ${ }^{\star} \&$ L. BUÉNO * \\ *Institut National de la Recherche Agronomique, Neuro-Gastroenterology and Nutrition Unit, Toulouse, France \\ †Ecole Supérieure d'Agriculture de Purpan, Toulouse, France
}

\begin{abstract}
Stressful life events are frequently associated with outward signs of irritable bowel syndrome (IBS). Increasing evidence suggests that acute and chronic stress stimuli implicate different physiological mechanisms and neuroendocrine responses. Therefore, we investigated the influence of acute and chronic stress on visceral nociception in female rats and the involvement of colonic mast cells in this effect. The effect of acute and chronic partial restraint stress (PRS) on visceral sensitivity to rectal distension (RD) was assessed by abdominal muscle electromyography. Colonic mast cell activation was determined by measuring histamine release after in vitro stimulation with substance $P(S P)$ in colonic samples from rats experiencing RD vs. controls. Acute PRS significantly enhanced abdominal response to $R D$ compared with sham PRS for all volumes of distension. In contrast, chronic PRS induced a hyperalgesic response for the highest volumes of distension $(0.8$ and $1.2 \mathrm{~mL})$, but did not affect the number of abdominal contractions for the lowest volume $(0.4 \mathrm{~mL})$ compared with controls. Both acute and chronic PRS increased in vitro $S P$-induced histamine release without affecting mast cell numbers. $R D$ induced similar in vitro histamine release from colonic samples from both acute and chronic PRS rats; this release, however, was significantly higher than that measured in sham-PRS rats. Acute and chronic PRS differently influence visceral sensitivity in response to $R D$ in female rats. This difference, however, cannot be attributed to a different
\end{abstract}

Address for correspondence

Dr L. Buéno, Neuro-Gastroenterology and Nutrition

Unit INRA, 180, chemin de Tournefeuille BP 03, 31931 Toulouse, France.

Tel.: + 33561 285143; fax: + 33561 285397;

e-mail: lbueno@toulouse.inra.fr

Received: 23 April 2001

Accepted for publication: 3 October 2001 effect of either stress paradigm on mast cell histamine release.

Keywords acute/chronic stress, female rats, histamine, visceral pain.

\section{INTRODUCTION}

Irritable bowel syndrome (IBS), characterized by abdominal pain or discomfort and altered bowel habit, ${ }^{1}$ affects mainly women. ${ }^{2}$ IBS patients frequently have increased levels of anxiety or psychological distress; moreover, stressful life events have been associated with the onset or exacerbation of IBS symptoms. ${ }^{3,4}$ Males and females may cope differently with psychological challenges and pain experience, resulting in a higher occurrence of IBS symptoms and prevalence of this disease in women. ${ }^{5,6}$ Preliminary results using psychological stress in healthy volunteers suggest a stress-induced increase in colon or rectosigmoid sensitivity to distension. ${ }^{7}$ Experimental studies in rats have shown that stress stimuli slow gastric emptying, increase distal colonic motility ${ }^{8}$ and decrease small intestinal transit. ${ }^{9}$ Furthermore, visceral hypersensitivity is connected to different stress stimuli in rat models of gut distension. ${ }^{10,11}$ Increasing evidence indicates that input from the central nervous system regulates gut function via complex interactions between the enteric nervous and immune systems. Thus, mast cells and neurones have been shown in intimate association and functional interaction in both the central and peripheral nervous systems. ${ }^{12}$ Therefore, mast cells appear pivotal as bi-directional information carriers linking the nervous and immune systems. Previous studies in animals indicate that stress induces gastrointestinal mast cell activation. Indeed, restraint stress in rats has been shown to activate mast cells in the colonic mucosa, resulting in increased mucin secretion. ${ }^{13}$ Furthermore, activation of ileal mast cells has been described during 
acute immobilization stress in rats ${ }^{14}$ and a recent study demonstrated that mild environmental stress affects the intestinal mucosa by increasing mucosal mast cell degranulation. ${ }^{15}$ Experimental studies evidenced that single acute stress stimuli and chronic repeated stress trigger different physiological mechanisms and neuroendocrine responses. ${ }^{16,17}$ Acute stress has been reported to enhance immune functions, whereas chronic stress may be immunosuppressive, decreasing leukocyte redistribution and inhibiting both cytokine and prostaglandin synthesis, and leukocyte function. ${ }^{18,19}$ However, both physical and quantitative characteris. tics of the stressing stimulus must be taken into account when investigating the influence of stress stimuli on the immune function. In addition, the gender may affect immune responsiveness to stress stimuli, as females have been shown to be more immunoreactive and susceptible to autoimmune diseases than males. ${ }^{20}$

Considering these data, we investigated whether the pattern of restraint stress (acute vs, chronic) may differently affect the nociceptive response to rectal distension in female rats. We further evaluated the relationship between mast cell degranulation and the visceral response to rectal distension in basal and stress conditions.

\section{MATERIAL AND METHODS}

\section{Animal preparation}

Female Wistar rats (Harlan, Gannat, France\}, weighing 200-250 g, were surgically prepared for electromyographic recording according to a previously described technique. ${ }^{21}$ Rats were anaesthetized by intraperitoneal (i.p.) injection of $0.6 \mathrm{mg} \mathrm{kg}^{-1}$ acepromazine (Calmivet; Vetoquinol, Lure, Francel and $120 \mathrm{mg} \mathrm{kg}^{-1}$ ketamine (Imalgene 1000, Rhône-Mérieux, Lyon, France). Three groups of three $\mathrm{NiCr}$ wire electrodes $\$ 60-\mathrm{cm}$ length, $80-\mu \mathrm{m}$ diameter) were implanted bilaterally into the abdominal external oblique muscle, just superior to the inguinal ligament. Electrodes were exteriorized on the back of the neck and protected by a glass tube attached to the skin. Rats were individually housed in polypropylene cages and kept in a temperature-controlled room $\left(21^{\circ} \mathrm{C}\right)$. They were allowed free access to water and food (UAR pellets; Epinay, France). All animal protocols were approved by the Local Animal Care and Use Committee of Institut National de la Recherche Agronomique.

\section{Partial restraint stress procedure}

All experiments were performed at the same period of the day (between 10.00 and $12.00 \mathrm{~h}$ ) to minimize any influence of circadian rhythms. Stress effects were studied using the wrap partial restraint stress (PRS) model. ${ }^{10}$ Thus, animals were lightly anaesthetized with ethyl ether (Prolabo, Paris, France) and their foreshoulders, upper forelimbs and thoracic trunk were wrapped in a confining harness of paper tape to restrict, but not impede, body movements. Rats were then placed into their home cage for $2 \mathrm{~h}$. Rats recovered from ethyl ether anaesthesia within 2-3 min and immediately moved around in their cages, although the restricted mobility of their forclimbs prevented grooming behaviour. Acute stress (A-PRS! consisted of a single 2 -h restraint session. For chronic stress [C-PRS], rats were restrained for $2 \mathrm{~h}$ a day for four consecutive days. Control sham-stress rats (sham PRS) were anaesthetized as above but were not wrapped and were allowed to move freely in their cages. The PRS at room temperature used in the present study is a mild and nonulcerogenic stress stimulus.

\section{Electromyographic recording}

Electromyographic recordings began 5 days after surgery. The electrical activity of abdominal striated muscles was recorded with an electroencephalograph (Mini VIII, Alvar, Paris, France) using a short timeconstant $\{0.03 \mathrm{~s})$ to remove low-frequency signals < $<3 \mathrm{~Hz} \mid$ and a paper speed of $3.6 \mathrm{~cm} \mathrm{~min}{ }^{-1}$.

\section{Rectal distension procedure}

Rats were placed in plastic tunnels $16 \mathrm{~cm}$ diameter, $25 \mathrm{~cm}$ length) into which they could not move, escape or turn around, in order to prevent damage to the balloon. They were accustomed to this procedure for 3 days before rectal distension ( $R D$ ), to minimize stress reactions during experiments. The balloon $12-\mathrm{mm}$ diameter, $2 \mathrm{~cm}$ long) used for distension was an arterial embolectomy probe (Fogarty; Edwards Laboratories Inc, Santa Ana, CA, USA). RD was performed by insertion of the balloon into the rectum, to $1 \mathrm{~cm}$ from the anus; the catheter was fixed to the tail with adhesive tape. The balloon was increasingly inflated in stepwise volumes of $0.4 \mathrm{~mL}$, from 0 to $1.2 \mathrm{~mL}$. Each step of inflation lasted $5 \mathrm{~min}$ and step-by-step distension was performed cumulatively from 0 to $1.2 \mathrm{~mL}$. The balloon and connected syringe were filled with tepid water in order to avoid temperature contrast. To detect possible leakage, the volume of water introduced into the bal. loon was checked by complete removal with a syringe at the end of the distension period. Both rectal distension procedure and electromyographic recording were performed as previously described. ${ }^{22}$ 


\section{Mast cell counting and histamine release}

Fifteen minutes after the end of either the single or last stress session, or 20 min after the last step of rectal distension, rats were killed and exsanguinated as approved by the local ethics committee. Two segments $(0.5 \mathrm{~cm})$ of distal colon were rapidly removed from each animal. For histological studies, one segment of distal colon was fixed in Carnoy's solution, cleared in xylene, and embedded in paraffin blocks. Transverse sections $(5 \mu \mathrm{m})$ were cut and submitted to a low-pH Alcian blue-safranin staining $(\mathrm{pH}=3)$, according to Roberts et al. ${ }^{23}$ This process permitted identification of resident mucosal mast cells, which appeared blue and are known to be in high proportion in the gut $96 \%$ in the large intestine). ${ }^{24}$ This counting included only blue mast cells in the mucosa and the submucosa / where mucosal mast cells have been clearly described $\left.\right|^{25}$ and was performed using coded slides to prevent observer bias. Mast cell counting was performed with a Nikon Microphot microscope using a $\times 20$ objective, coupled to a video-camera (JVC 3-CCD). The camera output was processed with an image-grabbing program (Neotech Image Grabber; Eastleigh, Hampshire, UK) and analysed by image-analysis software (Optilab Pro 2.6.1; Graphteck, Voisin le Bretonneux, France). At least three microscope fields $\left\{0.187 \mathrm{~mm}^{2}\right.$ field $\left.{ }^{-1}\right\}$ per organ section were examined and the number of intact mast cells expressed per $\mathrm{mm}^{2}$ as the mean value obtained for the different fields.

The second piece of colonic segment was cut longitudinally and was used for determination of tissue histamine release. Briefly, each colonic segment $(0.5 \mathrm{~cm})$ was incubated for $1 \mathrm{~h}$, in a Ringer's buffer solution containing $3 \times 10^{-5} \mathrm{~mol} \mathrm{~L}^{-1}$ substance $\mathrm{P}$ [SP acetate salt; Bachem, Voisins le Bretonneux, France), i.e. a concentration permitting maximal in vitro histamine release. Histamine levels in the supernatant were evaluated with a radioimmunoassay (RIA) kit using polyclonal histamine antibodies (Immunotech, Marseille, Francel. Histamine levels were expressed in nmol $\mathrm{g}^{-1}$ of tissue, and histamine values after SP stimulation were corrected for spontaneous histamine release in the absence of degranulating agent.

\section{Vaginal smear}

The hormonal status of each animal was evaluated by a vaginal smear after Haris-Shorr staining. Only females in pro-oestrus, which corresponds to a hormonal status combining both oestradiol and progesterone priming, were included in our studies just before the first stress session.

\section{Experimental procedure}

Two series of experiments were performed. In the first series, we investigated the influence of PRS procedure on colonic mast cells. Two groups of eight rats were submitted to either acute or chronic PRS, two other groups were submitted to the respective sham-PRS procedure (controls). Fifteen minutes after the end of the stress, rats were sacrificed, colonic samples were removed and in vitro histamine RIA and mast-cell counting were performed as previously described.

In the second series of experiments, we investigated the effects of PRS on the abdominal response to RD and determined whether colonic mast cell mediators are affected by this procedure. Four groups of eight rats equipped for electromyography were submitted either to acute or chronic PRS, or to respective shamstress procedures. Fifteen minutes after the end of the stress procedure, rats were placed in plastic tubes and submitted to rectal distension. Twenty minutes after the end of rectal distension, rats were killed and in vitro histamine release was measured in colonic samples.

\section{Statistical analysis}

Comparisons of the number of abdominal contractions for each 5-min period during rectal distension, histamine release and mast cell numbers between groups were performed by ANOVA followed by Student's paired or unpaired t-test as appropriate. Comparisons of histamine release triggered by rectal distension between sham-stress and stress, and between acute and chronic stress were assessed by a three-way ANOYA. Values are expressed as means \pm SEM. Differences were considered significant for $P<0.05$.

\section{RESULTS}

\section{Stress and visceral sensitivity}

In both the acute and chronic sham-PRS groups, gradual rectal distension $(R D)$ increased the frequency of abdominal contractions in a volume-dependent manner from the volume of $0.8 \mathrm{~mL}$. No significant change was observed in the number of abdominal contraction for the lowest volume $(0.4 \mathrm{~mL})$ compared with the basal situation (Table 1). Compared with sham A-PRS, A-PRS increased significantly the number of abdominal contractions for all volumes of distension. In contrast, compared with sham C-PRS, C-PRS enhanced significantly the number of 
Table 1 Abdominal response to rectal distension in shamstressed rats

\begin{tabular}{lllll}
\hline & \multicolumn{4}{l}{ Volume of rectal distension $\langle\mathrm{mL}\rangle$} \\
\cline { 2 - 5 } & 0 & 0.4 & 0.8 & 1.2 \\
\hline $\begin{array}{c}\text { Sham } \\
\text { A-PRS }\end{array}$ & $4.7 \pm 0.7$ & $4.8 \pm 1.3$ & $30.8 \pm 2.0$ & $39.0 \pm 4.2$ \\
$\begin{array}{c}\text { Sham } \\
\text { C-PRS }\end{array}$ & $4.1 \pm 0.6$ & $6.1 \pm 1.0$ & $24.0 \pm 2.8$ & $35.1 \pm 1.4$ \\
\hline
\end{tabular}

Data are reported as number of abdominal contractions during 5-min period of distension (mean \pm SEM). A similar gradual increase of abdominal muscle responses is observed for the two patterns of sham stress (acute vs. chronic). A-PRS, acute partial restraint stress; C-PRS, chronic partial restraint stress.

abdominal contractions only for the two highest steps of distension $(0.8$ and $1.2 \mathrm{~mL})$. The response was unaffected by C-PRS for the lowest volume of $0.4 \mathrm{~mL}$. Representative responses for non-nociceptive $(0.4 \mathrm{~mL})$ and nociceptive stimuli $(0.8,1.2 \mathrm{~mL})$ are presented in Figs 1 and 2a,b.

\section{Histamine release}

In vitro SP-stimulated colonic samples from sham PRS and PRS rats exhibited a significant release of histamine compared with vehicle-stimulated samples. After A-PRS, in vitro histamine release from colonic segments was significantly increased compared with

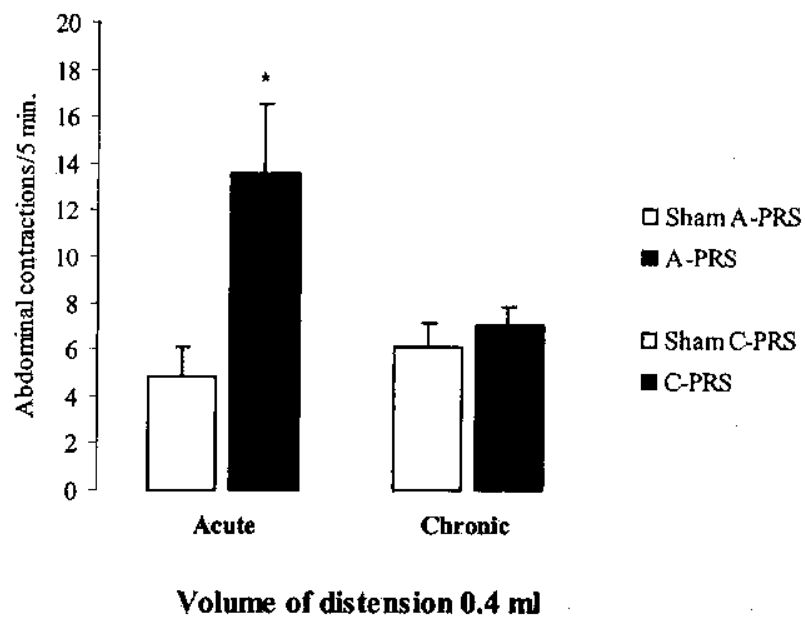

Figure 1 Effect of acute and chronic partial restraint stress (PRS) on abdominal contractions in response to nonpainful rectal distension $(0.4 \mathrm{~mL})$. Acute (A)-PRS significantly increased the number of abdominal contractions for this volume of distension whereas the abdominal muscle response was unaffected by chronic (C)-PRS. Values are means \pm SEM, $n=8 .{ }^{\star} p<0.05$; significantly different from corresponding sham PRS values.
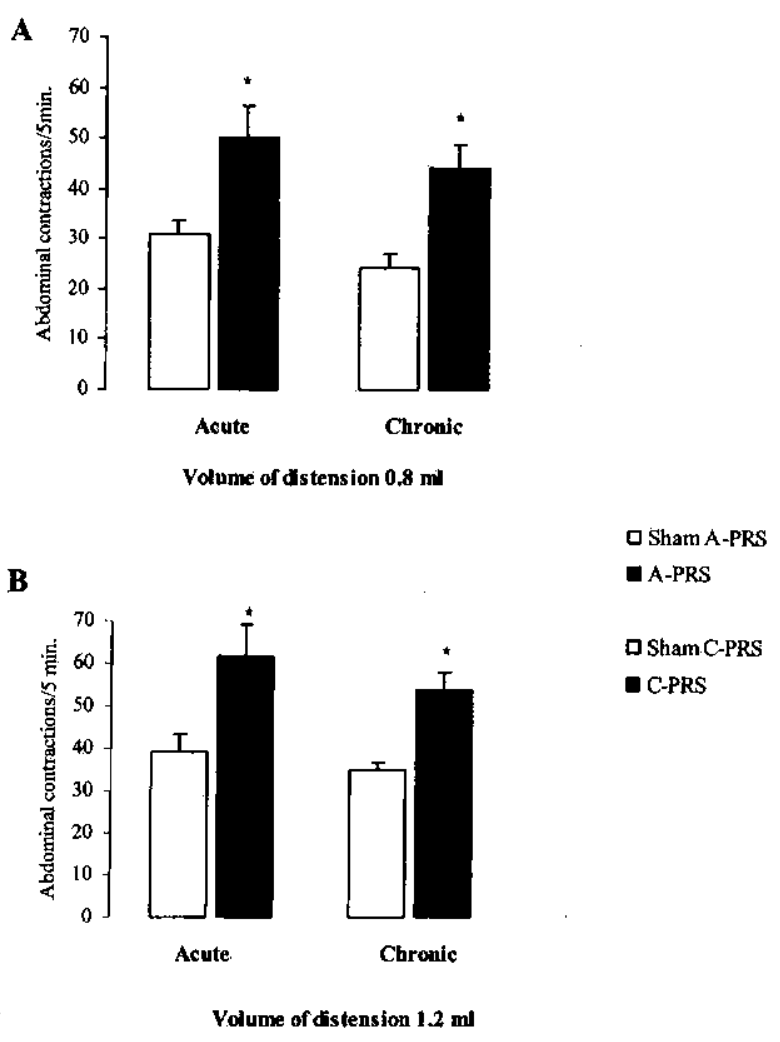

Figure 2 Effect of acute and chronic partial restraint stress (PRS) on abdominal contractions in response to painful rectal distension $\{a, 0.8 \mathrm{~mL} ; b, 1.2 \mathrm{~mL}\}$. Both acute and chronic PRS significantly increased the number of abdominal contractions for these volumes of distension. Values are means \pm SEM, $n=8$. ${ }^{\star} P<0.05$ : significantly different from corresponding sham PRS values.

sham A-PRS. Similarly, C-PRS resulted in an increased of in vitro histamine release from colonic samples after SP stimulation compared with sham C-PRS (Fig. 3).

Samples from sham A-PRS and sham C-PRS rats submitted to rectal distension exhibited a dramatic decrease of in vitro histamine release after SP stimulation compared with sham PRS rats without rectal distension. Similarly, rectal distension performed in A-PRS and C-PRS rats significantly decreased in vitro histamine release compared with nondistended animals (Fig. 3).

Histamine release induced by rectal distension in stressed rats (acute, chronic: $\Delta b, \Delta b^{\prime}$ ) was found to be significantly higher $(P<0.05)$ than that measured in corresponding sham-stressed rats $\left(\Delta a, \Delta a^{\prime}\right)$. In addition, statistical analysis evidenced that histamine release during rectal distension in A-PRS $(\Delta \mathrm{b})$ and C-PRS $\left(\Delta \mathrm{b}^{\prime}\right)$ were equivalent $(P=0.842)$. 


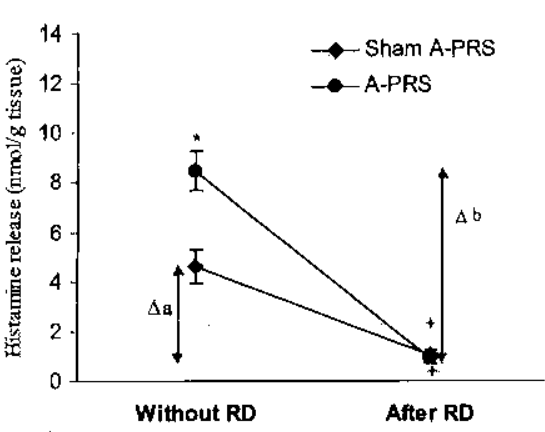

Acute PRS

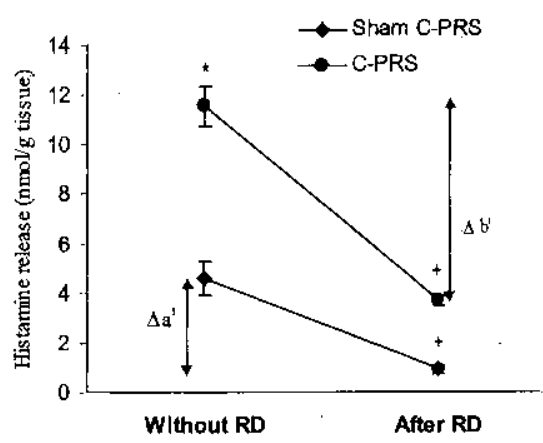

Chronic PRS

Figure 3 Histamine release after in vitro stimulation with substance $P$ of colonic samples from stressed and sham-stressed rats (acutc and chronic), submitted or not to rectal distension. Histamine release is significantly increased in nondistended acute and chronic partial restraint stressed (PRS) rats compared with corresponding sham P'RS. Rectal distension (RD) induced a reduction of in vitro histamine release in both stressed and sham-stressed animals. The amount of histamine relcased by rectal distension is indicated as $\Delta \mathrm{b}$ and $\Delta \mathrm{b}^{\prime}$ for acutc and chronic stressed rats and $\Delta \mathrm{a}$ and $\Delta \mathrm{a}^{\prime}$ for acute and chronic sham-PRS rats, respectively. Values are means $\pm \mathrm{SEM}, n=8{ }^{*} P<0.05$, significantly different from corresponding sham-stress values, $+P<0.05$ : significantly different from corresponding values in rats without $\mathrm{RD}$.

\section{Mast cell number}

Acute or chronic PRS did not affect the number of mast cells in the colon, which was found to be similar to that observed in sham-stressed animals (Fig. 4).

\section{DISCUSSION}

The present study indicates that acute and chronic PRS differently affect the response to rectal distension in female rats. Acute PRS enhanced visceral sensitivity in response to rectal distension with a lowering of the threshold volume perceived as a nociceptive stimulus. In addition, the magnitude of the abdominal response evoked by noxious stimuli (high volumes of distension)

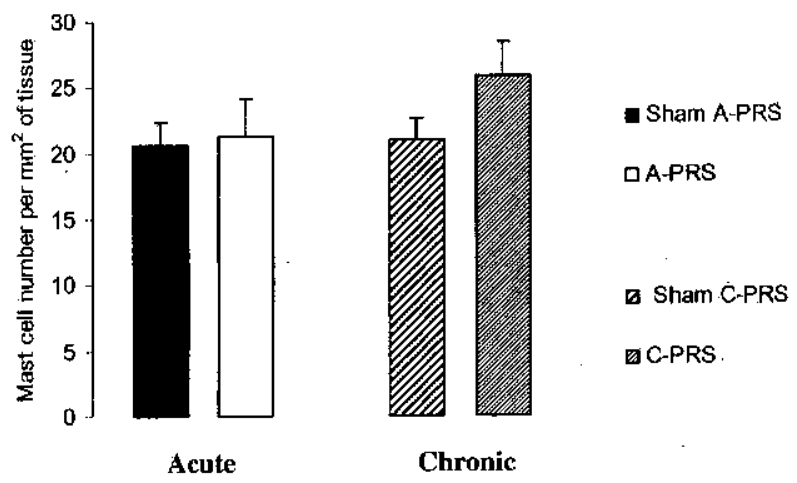

Figure 4 Mast cell numbers in colonic tissue of acute and chronic or sham partial restraint stressed (PRS) rats. Values are means $\pm S E M, n=8$. Statistically significant differences were not found between groups. was found to be increased following acute PRS. In contrast, chronic PRS induced visceral hyperalgesia, characterized by enhanced abdominal response to high volumes of distension, but did not affect the sensitivity threshold. The stress-induced increase of visceral sensitivity reported in this study for acute PRS is in agreement with previous findings using restraint or perinatal stress in rats, ${ }^{10,11}$ but the lack of effect of chronic stress on the sensitivity threshold to rectal distension was unexpected.

Restraint in rats is a mild and nonulcerogenic stressor activating the hypothalamic-pituitary-adrenal (HPA) axis. This activation results in an increased plasma adrenocorticotropin hormone (ACTH) and corticosterone levels. ${ }^{26}$ However, stimulation of the HPA axis is affected by the chronicity and severity of stress. ${ }^{27}$ Indeed, while acute stress is characterized by increased corticosterone levels, chronic stress patterns mainly correspond to diminished corticosteroid levels. A recent study reported that decreased corticosterone response in chronically stressed rats is associated with decreased expression of corticotropin-releasing hormone (CRF) mRNA in the paraventricular nucleus (PNV). ${ }^{28}$ CRF peripherally administered to healthy humans decreases the threshold and increases the intensity of discomfort in response to rectal distension. ${ }^{29}$ In rats, central administration of CRF has been found to increase the number of abdominal contractions in response to rectal distension, mimicking the effect of stress. ${ }^{10}$ As brain CRF has been suggested to play a role in recto-colonic sensitivity, changes in CRF mRNA expression in the PNV of chronically stressed 
rats may explain the lack of effect on the threshold in the C-PRS paradigm compared to A-PRS.

An involvement of mast cells in stress-induced hypersensitivity to rectal distension has been proposed since doxantrazole was shown to abolish this effect. ${ }^{10}$ Therefore, we investigated the influence of the stress pattern on mast cell content using in vitro histamine release as an indicator of mast cell activation. Our data indicate that both acute and chronic PRS similarly increase both mast cell histamine synthesis and sensitivity to $\mathrm{SP}$, as shown by an increase in histamine release after SP stimulation in colonic samples of stressed rats. However, the number of mast cells was also unchanged after C-PRS, as has previously been shown for A-PRS. ${ }^{30}$ This result is consistent with a previous study, ${ }^{30}$ and suggests a modulatory role of stress on mast cell mediators, independent of stress stimuli chronicity, resulting in enhanced levels of histamine content. Increase of histamine mast cell content in rat jejunal mucosa without degranulation has previously been reported after electrical stimulation of cervical vagi. ${ }^{31}$ However, we cannot exclude that colonic mast cells may become more sensitive to SP stimulation after stress. Indeed, some evidence supports the hypothesis of an. increased cellular responsiveness to subsequent stimuli when mast cells were previously submitted to a first stimulation with SP. ${ }^{32}$ As stress has been found to increase SP levels in the peritoneal fluid of mice, ${ }^{33}$ we can hypothesize that mast cells may be primed during stress and become more sensitive to a further in vitro stimulation by $\mathrm{SP}$.

Our results also show a decrease of histamine release after SP stimulation in colonic samples from shamPRS rats submitted to rectal distension. These data suggest a depletion of mast-cell mediators induced by rectal distension, and are consistent with previous findings suggesting that histamine release from mast cells is triggered by rectal distension in rats. ${ }^{30}$ However, a greater depletion of mast cell content in response to rectal distension (a parietal mechanical stimulus) was observed in samples from acute and chronic PRS rats compared with sham PRS. We can first hypothesize that direct physical stimulation of mast cells produced their degranulation. Such a direct activation induced by colonic mucosa stimulation has been proposed for serotonin secretion from enterochromaffin cells mediating both gastrocolonic response and peristaltic reflex. ${ }^{34,35}$ In addition, mechanoreceptors located on afferent nerve endings in the colon wall may be activated by distension, and through axon reflex may release a range of neuromediators likely to induce mast cell activation, including $\mathrm{SP}^{36}$
Degranulation of mast cells can result in the release of mediators such as histamine, serotonin and cytokines, known to facilitate the response of afferent fibres to nociceptive stimuli, ${ }^{37}$ Indeed, the close proximity between mast cells and sensory neurone endings may lead to an amplifying loop and result in sensitization of the nerve endings and increased responses to painful stimuli. This process can be hypothcsized in the stressinduced visceral hypersensitivity observed in our study because a greater release of mast cell mediators was obscrved in stressed animals. Among these mediators, histamine is reported to play an important role in the modulation of central perception of nociceptive stim$\mathrm{uli}_{\text {, }} 38,39$ however, the involvement of histamine peripherally in the activation of nociceptors within the gut is only partly documented. A pronociceptive potency of histamine through $\mathrm{Hl}$ receptor activation has been suggested in both somatic and visceral pain in mice. ${ }^{40}$ In contrast, a recent study evidenced that histamine did not play a significant role in the induction of delayed rectal allodynia triggered by in vivo administration of $\mathrm{BrX} 537 \mathrm{~A}$, a mast cell degranulator in rats. ${ }^{41}$ Considering these data, the hypothesis that histamine released from mast cells during rectal distension is involved in the stress-induced visceral hyperalgesia remains to be investigated further. We cannot exclude, however, the possibility that stress affects the synthesis or secretion of other mediators from mast cells or other immunocytes involved in thesensitization of primary afferent nerve endings. Accordingly, sensitization of visceral afferents with high and low threshold for mechanical stimulation could be involved in the development of visceral hypersensitivity in acute and chronically stressed animals. Furthermore, we cannot exclude the involvement of the central amygdala region in the regulation of visceral response to stress. Indeed, restraint stress was shown to enhance c-fos expression in the cortical amygdala of rats. ${ }^{42,43}$ In addition, activation of cortical amygdala is known to initiate antinociceptive processes. ${ }^{44}$ Then, sustained activation of this limbic structure during chronic PRS can be suggested to induce increased activation of inhibitory descending neuronal pathways. This hypothesis can be considered to explain the lack of effect on the threshold in C-PRS compared to A-PRS. Alternatively, adaptation processes have been suggested when a stress stimulus is presented as a series of 'acute' presentations accruing over days. However, recent data using restraint stress in rats confirmed that restraint was still perceived as stressful throughout a 4-day exposure period. ${ }^{45}$ Taken together, these data support the hypothesis that acute and chronic stress may engage different physiological 
mechanisms involved in visceral sensitivity, as previously shown for the inflammatory response. ${ }^{45}$

In conclusion, this study demonstrates that acute and chronic partial restraint stress differently affect visceral sensitivity in response to painful and nonpainful rectal distension in female rats. We show that mast cell histamine content is increased after both acute and chronic partial restraint stress and that rectal distension induces a similar depletion of histamine from colonic mast cells of acute and chronically stressed animals. Consequently, stress-induced changes in mast cell histamine content do not appear to be involved in the different effects observed on visceral sensitivity for acute and chronic stress. Although the precise mechanism remains to be elucidated, these results show the influence of stressor chronicity on visceral nociceptive responses.

\section{ACKNOWLEDGMENTS}

This work was supported by a grant from the 'Fondation pour la Recherche Medicale ${ }^{\prime}$ (FRM) and the institutional support of INRA, Paris, France.

\section{REFERENCES}

1 Thompson WG, Longstreth GF, Drossman DA, Heaton $\mathrm{KW}$, Irvine EJ, Muller-Lissner SA. Functional bowel disorders and functional abdominal pain. Gut 1999; 45: 43-7.

2 Thompson WG, Heaton KW, Smyth GT, Smyth C. Irritable bowel syndrome: the view from general practice. Eur $I$ Gastroenterol Hepatol 1997; 9: 689-92.

3 Drossman DA, Creed FH, Olden KW, Svedlund J, Toner $\mathrm{BB}$, Whitehead WE. Psychosocial aspects of the functional gastrointestinal disorders. Gut 1999; 45: 25-30.

4 Collins S, Barbara G, Vallance B. Stress inflammation and the irritable bowel syndrome. Can / Gastroenterol 1999; 13: 47-9.

5 Unruh AM. Gender variations in clinical pain experience. Pain 1996; 65: 123-67.

6 Verbrugge LM. Gender and health: an update on hypotheses and evidence. I Health Soc Behav 1985; 26: 156-82.

7 Ford MJ, Camilleri M, Zinsmeister AR, Hanson RB. Psychosensory modulation of colonic sensation in the human transverse and sigmoid colon. Gastroenterology 1995; 109: 1772-80.

8 Monnikes H, Schmidt BG, Taché Y. Psychological stressinduced accelerated colonic transit in rats involves hypothalamic corticotropin-releasing factor. Gastroenterology 1993; 104: 716-23.

9 Williams CL, Villar RG, Peterson JM, Burks TF. Stressinduced changes in intestinal transit in the rat: a model for irritable bowel syndrome, Gastroenterology 1988; 94: 61121.

10 Gue M, Del Rio-Lacheze C, Eutamene $H_{t}$ Theodorou V, Fioramonti I, Bueno L. Stress-induced visceral hypersensitivity to rectal distension in rats: role of CRF and mast cells. Neurogastroenterol Mot 1997; 9: 271-9.
11 Coutinho SV, Sablad MR, Miller JC et al. Neonatal maternal separation results in stress-induced visceral hyperalgesia in adult rats: a new model for IBS. Gastroenterology 2000, 118: A637.

12 McKay DM, Bienenstock J. The interaction between mast cells and nerves in the gastrointestinal tract. Immunol Today 1994; 15: 533-8,

13 Castagliuolo I, Lamont JT, Qiu B et al. Acute stress causes mucin release from rat colon: role of corticotropin releasing factor and mast cells. Am / Physiol 1996; 271: G88492.

14 Theoharides TC, Letourneau R, Patra P et al. Stress-induced rat intestinal mast cell intragranular activation and inhibitory effect of sulphated proteoglycans. Dig Dis $S C i$ 1999; 44: 87S-93S.

15 Wilson LM, Baldwin AL. Environmental stress causes mast cell degranulation, endothelial and epithelial changes, and oedema in the rat intestinal mucosa. Microcirculation 1999; 6: 189-98.

16 Garcia A, Marti O, Valles A, Dal-Zotto R, Armario A. Recovery of the hypothalamic-pituitary-adrenal response to stress. Effect of stress intensity, stress duration and previous stress exposure. Neuroendocrinology 2000; 72: 114-25.

17 Dantzer R, Kelley KW. Stress and immunity: an integrated view of relationships between the brain and the immune system. Life Sci 1989, 44: 1995-2000.

18 Millan S, Gonzales-Quijano MI, Giordano M, Soto L, Martin AI, Lopez-Calderon A. Short and long restraint differentially affect humoral and cellular immune functions. Life Sci $1996 ; 59 ; 1431-42$.

19 Dhabhar FS, Miller AH, McEwen BS, Spencer RL. Stress induced changes in blood leukocyte distribution; Role of adrenal steroid hormones. I Immunol 1996; 157: 163844.

20 Grossman CJ. Regulation of the immune system by sex steroids, Endocr Rev 1984; 5: 435-55.

21 Ruckebusch $M$, Fioramonti J. Electrical spiking activity and propulsion in small intestine in fed and fasted rats. Gastroenterology 1975; 68: 1500-8.

22 Morteau O, Hachet T, Caussette M, Bueno L, Experimental colitis alters visceromotor response to colorectal distension in awake rats. Dig Dis Sci 1994; 39: 1239-48.

23 Roberts ISD, Jones CJP, Stoddart RW. Lectin histochemistry of the mast cell; heterogeneity of rodent and human mast cell population. Histochem / 1990; 22: 73-80.

24 Saavedra-Delgado AM, Turpin S, Metcalfe DD. Typical and atypical mast cells of the rat gastrointestinal system: distribution and correlation with tissue histamine. Agents Actions 1984; 14: 1-7.

25 Nakijama S, Arizono N, Hattori T, Bamba T. Increase in mucosal and connective tissue-type mast cells in the stomach with acetic acid-induced ulcer in rats. APMIS 1996; 104: 19-29.

26 Strausbaugh H, Dallman MF, Levine JD. Repeated but not acute, stress suppresses inflammatory plasma extravasa. tion. Prot Nat Acad Sci USA 1999; 96: 14629-34.

27 Mayer EA. The neurobiology of stress and gastrointestinal disease. Gut 2000; 47; 861-9.

28 Albeck DS, McKittrick CR, Blanchard DC et al. Chronic social stress alters levels of corticotropin-releasing factor and arginine vasopressin $\mathrm{mRNA}$ in rat brain. / Neurosci 1997, 17: 4895-903. 
29 Lembo $T$, Plourde $\mathrm{V}$, Shui $\mathrm{Z}$ et al. Effects of the corticotropin-releasing factor (CRF) on rectal afferent nerves in humans. Neurogastroenterol Mot 1996, 8: 9-18.

30 Eutamene $H$, Theodorou V, Vergnolle N, Comera C, Fioramonti I, Bueno $\mathrm{L}$. Involvement of interleukin-1, prostaglandins and mast cells in rectal distension-induced colonic water secretion in rats. / Physiol (Lond) 1998; 506: 245-52.

31 Gottwald TP, Hewlett BR, Lhotak S, Stead RH. Blectrical stimulation of the vagus nerve modulates the histamine content of mast cells in the rat jejunal mucosa. Neuroreport 1995, 29: 313-7.

32 Janiszewski J, Bienenstock J, Blennerhassett MG. Picom olar doses of substance P trigger electrical responses in mast cells without degranulation. Am / Physiol 1994; 267: C138-C145.

33 Chancellor-Freeland C, Zhu GF, Kage R, Beller DI, Leeman SE, Black PH. Substance $P$ and stress-induced changes in macrophages. Ann N Y Acad Sci 1995; 771: 472-84.

34 Bülbring E, Crema A, The release of 5-hydroxytryptamine in relation to pressure exerted on the intestinal mucosa. I Physiol (Lond) 1959, 146: 381-407.

35 Foxx-Orenstein AY, Kuemmerle JF, Grider JR. Distinct 5 -HT receptors mediate the peristaltic reflex induced by mucosal stimuli in human and guinea pig intestine. Gastroenterology 1996; 111: 1281-90.

36 Colburn RW, Coombs DW, Degnan CC, Rogers LL. Mechanical visceral pain model: chronic intermittent intestinal distension in the rat. Physiol Behav 1989; 45: 191-7.
37 Levine I, Taiwo Y. Inflammatory pain, In: Textbook of Pain. PD Wall R Lelzack, eds. Edinburgh: Churchill Livingstone, 1994: pp. 45-56.

38 Malmberg-Aiello P, Lamberti C, Ghelardini C, Giotti A, Bartolini A. Role of histamine in rodent antinociception. Br / Pharmacol 1994, 111: 1269-79.

39 Lamberti C, Bartolini A, Ghelardini C, Malmberg-Aiello P. Investigation into the role of histamine receptors in rodent antinociception. Pharmacol Biochem Behav 1996; 53: 567-74.

40 Mobarakeh II, Sakurada S, Katsuyama S, Kutsuwa M, Kuramasu A, Lin ZY, Watanabe T, Hashimoto Y, Yanai K. Role of histamine $\mathrm{H}(1)$ receptor in pain perception: a study of the receptor gene knockout mice. Eur / Pharmacol 2000; 391: 81-9.

41 Coelho AM, Fioramonti J, Bueno L. Mast cell degranulation induces delayed rectal allodynia in rats: role of histamine and 5-HT. Dig Dis Sci 1998, 43: 727-37.

42 Traub RJ, Sílva E, Gebhart GF, Solodkin A. Noxious colorectal distention-induced c-Fos protein in limbic brain structures in the rat. Neurosci Lett 1996, 215: 165-8.

43 Chowdhury GM, Fujioka T, Nakamura S. Induction and adaptation of Fos expression in the rat brain by two types of acute restraint stress. Brain Res Bull 2000; 52: 171-82.

44 Sha L, Huang P, Ding W, Teng G. The inhibitory effects of stimulating $\mathrm{AC}, \mathrm{AL}, \mathrm{BNST}$ and $\mathrm{AHL}$ on visceral pain. Zhen CI Yan Jiu 1993, 18: 37-43.

45 Strausbaugh HJ, Dallman MF, Levine JD. Repeated but not acute stress suppresses inflammatory plasma extravasation. Prot Nat Acad Sci USA 1999; 96: 14629-34. 